\title{
Key Factors Affecting Lecturer Productivity to Conduct Research
}

\author{
${ }^{1}$ Dewi Andriani", ${ }^{2}$ Dedi Purwana ES., ${ }^{3}$ Dan Dewi Susita
}

${ }^{1}$ Doctoral Program of HRM Department, Universitas Negeri Jakarta, Indonesia, Jl. Rawamangun Muka, Jakarta 13220, Indonesia

${ }^{2,3}$ Lectures at HRM Department, Universitas Negeri Jakarta, J1.Rawamangun Muka Jakarta 13220, Indonesia

\begin{abstract}
The effectiveness of higher education institutions must be measured in terms of research productivity, the ability to produce new knowledge in the form of research and publications. In this case, lecturers as academic staff are expected to have a high level of capacity, commitment, integrity and responsibility to achieve the stated teaching and learning goals. Then, the global challenges that must be faced increasingly demand the role of lecturers to be able to further improve their work performance to conduct research and publish it in reputable international journals such as Scopus Idexed and others. Lecturers are one of the important factors for creating competent university graduates, and the main role of tertiary institutions is teaching, research and community service and is directed to expand knowledge and open new avenues of science and technology. This study aims to analyze the factors that influence the productivity of lecturers producing international scientific articles at Private Universities using Structural Equation Modeling. The data used are primary data by conducting surveys with a total of 310 respondents, and the analysis used includes validity, reliability, multiple linear regression, multiple tests, and hypothesis testing. The results showed that the positive direct effect of transformational leadership style and communication on lecturer productivity. Both of these exogenous variables, transformational leadership style has a path coefficient value of py1 of 0.201 and $\mathrm{CR}$ (tcount) of 3.715 , while the communication variable proves to be the most dominant influence on productivity as an endegent variable, 5,132.
\end{abstract}

Keywords: Transformational Leadership Style, Communication, Lecturer Productivity, Scientific Articles and Structural Equation Modeling.

\section{Statement of the Problem}

Based on data from the Directorate of Intellectual Property Management of the Directorate General of Research and Development Strengthening Kemenristek Dikti and processed from various other sources shows that the productivity ratio of lecturers which is the work or performance of lecturers as researchers in the publication of international scientific works in the 3 (three) private universities is relatively still low, $30.40 \%$. That is, it is still far from the provisions regulated as mandated by various regulations and applicable legislation as in Permenristekdikti Number 20 Year 2017 Law No 14 of 2005 article 1 paragraph 2 About Teachers and Lecturers, Law No 12 of 2012 article 12 paragraph 2 Regarding Higher Education, PAN-RB Ministerial Regulation Number 17 of 2013, Regulation of the Minister of Education and Culture of the Republic of Indonesia Number 78 of 2013. Thus, this becomes a critical issue and is a research gap in this study so that it becomes the interest of researchers to conduct research and make it as a the subject matter (Statement of Problem), the influence of transformational leadership style and communication on the productivity of lecturers in private universities as a scientific study. Furthermore, the significance of this research is to find out: "Is there an influence of transformational leadership style and communication on the productivity of lecturers producing international scientific work in private universities?"

\section{Theoritical of Framework}

According to Leblebici (2012), an increase in performance can be interpreted as functional and organizational productivity including: quality, namely the ratio to measure how well an organization (or individual, industry, country) to change the input resources in the form of labor, materials, machinery, etc. others become goods and services. Research performance in the academic world usually refers to scientific progress, mostly published in academic journals (Cadez et al., 2016). According to Mustapa \& Mahmood 
(2016), job performance is a key term applied to describe how well an employee's performance relates to his duties, and must be seen as behavior rather than results. According to experts in Okonedo (2015) that the productivity of publications is expressed by the number or quantity of papers published by the units selected in a certain time, and the quantity indicators for research for example: the number of publications, citations, and grants (Cadez et al., 2016).

According to Iqbal and Mahmood (2011:189), productivity of publications is a paper that is published and produced by selected units within a certain time in the form of real results from research and published in professional journals, conference processes, writing books or chapters in books, working with post-graduate students scholars in dissertations, and class projects, carrying out editorial assignments, obtaining patents and licenses, writing monographs, developing experimental designs, producing works that are artistic or creative and involved in public debates and comments. Whereas the notion of research can be interpreted as a rigorous, systematic, validating, verified, empirical, critical, analyzing and interpreting process of information to answer questions by collecting, verifying, and analyzing information (Ifijeh et al.,2018) and research is an ongoing process, namely seeking the truth or trying to approach reality (Iqbal \& Mahmood, 2011: 189). According to experts as quoted by Agustini et al., (2014), the notion of productivity is not only "doing something right" to achieve maximum performance, but "the right thing" to achieve maximum effectiveness, namely as what people can produce with less effort and as employee hourly outputs by considering quality as well as improving functional and organizational performance, including quality.

According to Kim \& Ployhart (2014), performance is operationalized in terms of employee productivity in the form of an organization / company workforce efficiency to produce outputs. Higher education outputs are in the form of journal articles, published books, chapters in books, technical reports, conference papers, seminar papers, edited works, workshop papers, theses and other types of publications (Ifijeh et al., 2018). Outputs are closely related with human resource activities and performance measures that include efficiency and effectiveness (Upev et al.,2015). Aderibigbe (2017: 76-77) describes that employee productivity is related to the extent to which members of the organization contribute to achieving organizational goals. While organizational success is dependent on employee performance, such as: employees who are creative, innovative, and committed (Al Doghan \& Albar, 2015). Productivity in the education sector can be taken as a measure of the success of operations of activities that will lead to the realization of sector goals and targets in the economy as it applies to other forms of business or company organization (Adu, 2015), and the effectiveness of higher education institutions must be measured based on research productivity these institutions, the ability to generate new knowledge in the form of publications using their active resources as a result of the institution (Aithal, 2016).

Universities as universities can be interpreted as modern organizations that are actually managed based on professionalism and have the characteristics, assume the average academic and non-academic employees are as human resources (HR) and institutional human capital. Therefore, the importance of productivity for the success of higher education requires that lecturers / teachers as academic staff can have a high level of capacity, commitment, integrity and responsibility to achieve predetermined teaching and learning goals (Adu, 2015). From the various descriptions of the experts, it can be synthesized that the notion of lecturer productivity is an aggregate of lecturer performance to produce international scientific work that is influenced by the reward system, leadership style, communication and motivation. Then, the notion of transformational leadership style can be interpreted as a leader behavior that changes and inspire followers to do work beyond self-interest for the good of the organization by promoting intellectual development, selfconfidence, team spirit and enthusiasm among followers, thus encouraging followers to focus more on collective well-being to achieve organizational goals ((Veliu et al., 2017; Aydin et.al, 2013) The study of the influence of leadership behavior on employee work shows a positive relationship because leadership is a process of interaction between leaders and followers in which leaders try to influence followers to achieve shared goals (Voon et.al., 2011). Leaders have a variety of ways to influence creativity in organizations and their followers by changing leadership styles. In this way, the leader can be interpreted as being able to build a positive collective socio-emotional psychological state or a mood that fosters a high level of future creativity. 
In this case, the notion of leadership is the ability to guide followers towards common goals, to influence and motivate others to do certain jobs or tasks to achieve the goals of the organization that have been determined (GO, 2015) and (Iqbal et al., 2015). Furthermore, leadership conceptualization consists of relational tasks and behaviors which are considered as leadership style approaches where leaders help their teams achieve their personal work targets and team targets by informing them of the right methods and direction and communicating effectively to achieve these goals ( Luthra \& Dahiya, 2015); and (Veliu et al., 2017) so that organizational success depends on the leader and his leadership style (Iqbal et al., 2015). Furthermore (Ahmad et al., 2014); and (Aydin et al., 2013) states that the notion of transformational leadership style is to have four dimensions consisting of: idealized influence (Individualized Influence), individual consideration (Intellectual Stimulation) and inspirational motivation (Inspirational Motivation) which described as follows:

1. Idealized Influence: They feel proud and dignified by having courageous leaders and influencing employee motivation in a positive way, leaders who are charismatic, ability, consistency and determination in dealing with problems, dare to take risks, have ethics and determination who are high in their behavior and in this way.

2. Individual Consideration): The quality of this leader is able to inspire, train subordinates and stimulate them to gain experience to achieve the goals and objectives of the company through policies such as: giving recommendations or recognition and recognition in the form of money and nominal wages to employees who excel. optimally, leaders give employees the authority to meet their work needs and act according to directions, so employees dedicate more time and employees are stimulated to achieve high levels of motivation.

3. Intellectual Stimulation: Transformational leaders motivate followers in new ways, make employees creative, and they become good decision makers and always direct employees to find solutions to problems logically so that it influences subordinates to be more creative, critical and logical.

4. Inspirational Motivation: Leaders motivate followers by accepting challenges and also acting as a model for them, inspiring to achieve goals effectively by explaining the meaning of challenges to be faced about future goals and the true vision of the organization and commitment to goals so these leaders become a symbol of courage and a model to stimulate subordinates to work and encourage them to get more than they want for their own interests and encourage employees to express some new ideas then they can freely describe their internal feelings and unique ideas because they feel that their ideas will be supported by leaders.

From the various descriptions of the experts it can be synthesized that the notion of transformational leadership style is the behavior of leaders as agents of change, inspiring and increasing the motivation and productivity of lecturers to produce productivity of international scientific work. Then, quality human resources (HR), communication in an organization has an important and very strategic role in achieving organizational goals.

Furthermore, the definition of communication according to Femi (2014) includes all the activities a person does when he wants to make a transformation in the minds of others. According to (Luthra \& Dahiya, 2015), communication is transferring information or messages from one person to another or to a group and effective leadership communication, transferring messages keeping in mind the recipient's understanding and ability and ensuring that the recipient will be able to find the right meaning of message or information passed on to him. According to Ruck \& Welch, (2012), the role of communication is an important factor in understanding the value of intangible organizational assets because communication in organizations is associated with higher levels of performance and services resulting in communication capital and social capital based on organizational relationships. According to Muda et al., (2014), the importance of communication to be applied in organizations is to influence bottom-line, increase employee work productivity.

Therefore, good organization can be achieved if there is a good communication climate (Luthfie et.al., 2017). A good climate of communication within the organization shows that there is a harmonization of communication between leaders and members, between superiors and subordinates, between leaders, or among members so that the creation of communication satisfaction in the organization / company and affect 
employee performance (Gusfa et al., 2017). According to Ahsanul (2013), an organization's communication climate is important because its purpose is to connect the organizational context with concepts, feelings and expectations, helping to explain the behavior of organizational members and function as a liaison between individual employees and the organization (Nordin et al., 2014). Then, (Ahsanul, 2013) states that that the effect of communication through an interactive process of organizational members is that members of the organization can determine and confirm the reality of existence within the organization. Furthermore, Ajala (2012) states that effective communication in the workplace plays an important role in developing success and professionalism because the organizational structure determines the knowledge gained and how they communicate with one another.

According to Caliendo \& Rossi-hansberg (2012), the reality that exists in many organizations, is that employees do not know what mission, vision, objects are, while on one side employees are an integral part of the organization can be an effective way to get the most out of talent or competencies brought to the organization by each employee (Sageer et.al., 2012). The role of leaders communicates effectively to translate and operationalize the mission, vision, objects, and provide accurate and adequate information about the organization (Redding, 1972 in Ahsanul, 2013) thus gaining the trust of followers, which in turn helps in satisfying communication between leaders and followers. In other words, when leaders communicate effectively, their followers experience a greater level of satisfaction because communication contains a relational component (affective) and a task (content) consisting of communicator competence, leadership, communication satisfaction, and job satisfaction in leadership.

According to Gusfa et al., (2017), organizational communication plays a large role in the company's growth, both financially and in the competencies of the people in it. According to (Ajala, 2012), the role of effective communication in an organization's work environment is to avoid and resolve various problems that might occur so as to produce stronger morals and more positive attitudes towards work. Furthermore, some experts according to (Ajala, 2012), stated that the importance of communicating effectively (Luthra \& Dahiya, 2015) with each other so that employee productivity will increase because effective communication means less complaining and more work being completed and making the workplace more enjoyable, less anxiety among coworkers which in turn means a positive attitude towards work and increased productivity. From the various descriptions of the experts, it can be synthesized that the notion of communication is transferring information or messages that contain relational components (affective) and tasks (content) from one person to another or to a group effectively in order to increase the motivation and productivity of lecturers to produce work international science.

\section{Methodology}

\section{Design of the Study}

The research method used in this research is explanatory research with a quantitative approach. Explanatory research is research that aims to explain the position of the studied variables and the relationship between research variables (Sugiyono, 2012). As far as researchers' knowledge and observations, there is actually no empirical study that has specifically examined the effect of transformational leadership styles and communication on the productivity of lecturers producing scientific article. international at Private University. Then, the potential impact of these two factors is very important to the productivity of lecturers producing international scientific work at Private Universities. According to Creswell (2013) and Kumar (2011), this design is considered appropriate because it allows this research to get a very basic insight about the occurrence of a phenomenon, situation, attitude and or problem.

\section{Context and Participants}

This research was conducted at Trisakti University, Bina Nusantara University and Tarumanagara University. As is well known that the productivity of lecturers in Indonesia in terms of conducting research is indicated to tend to lose in terms of productivity of Scopus Indexed international scientific publication publications when compared to researchers from Malaysia and Thailand. This condition is a general reality that occurs in various universities both State Universities and Private Universities in Indonesia. According to Nasir (2019), currently there are 5,500 people, while there are only 2,250 people doing research and publication of their work, there are still many professors in a number of universities in Indonesia not doing research and publications. "Professors must certainly do research and publications, not just just enjoy the 
honor allowance "said Nasir in Padang, Wednesday (3/13/2019) as quoted Antaranews.com. (Higher Education: 2,250 Professors do not do research and publications, https://beritagar.id/artikel/berita/2250profesor-takakukan-riset-dan-publikasi . Accessed March 15, 2019). Therefore, this study involved academic staff at Trisakti University, Bina Nusantara University and Tarumanagara University $(\mathrm{n}=310)$. The lecturers chosen in this study because of their work performance, as well as other types of employees in different occupations, are mostly dependent and / or influenced by the workplace environment (Hertzberg et al., 1959]). As such, it is believed that they can provide relevant opinions on what constitutes a work environment conducive to donation and the potential effects of work environment factors that are prevalent on their job performance. The distribution of respondent / sample characteristics in this study consisted of gender, last education, age, and length of time working as a lecturer at the university, shown in Table 1.

Table 1: Characteristics of Respondents $(n=310)$

\begin{tabular}{|c|c|c|}
\hline $\begin{array}{c}\text { Characteristics of } \\
\text { Respondents }\end{array}$ & Category & Total \\
\hline 1. Gender & Male $=191 ;$ Female $=119$ & 310 \\
\hline 2. Eeducation & $\mathrm{S} 1=14 ; \mathrm{S} 2=201 ; \mathrm{S} 3=95$ & 310 \\
\hline 3. Age & $\begin{array}{c}<30 \text { years }=26 ; 31-40 \text { years } ; 41-50 \text { years } ; 51-60 \text { years } \\
=93 ; 61-70 \text { years }=24 ; \geq 71 \text { Years }=5\end{array}$ & 310 \\
\hline 4. Length of work & $1-10$ years $=132 ; 11-20$ years $=74 ; 21-30$ years $=87 ;$ & 310
\end{tabular}

\section{Source: Diolah dari hasil penelitian}

$$
31-40 \text { years }=17
$$

\section{Data Analysis}

Descriptive analysis was conducted to determine respondents' responses to research variables, namely lecturer productivity variables in producing reputable international scientific work (Y) along with the variables that influence it, such as transformational leadership style (X1), and communication (X2). The steps in the descriptive analysis are: (1) The description of the answers / responses of respondents to the research instrument is presented based on the description of the answers to each variable. But before that a standard / size must be determined in decision making in the description of the instrument's answers; and (2) To measure the description of the answers, class intervals and class scale ranges are needed. These variables are assessed based on the arithmetic mean of the answers of 310 respondents. Assessment of respondents' perceptions was given a score of 1 for very low / not good answers and a score of 5 for very high / very good answers. Descriptive statistics are used to summarize and describe participants' responses, the results of the descriptive analysis in Table 2, Table 3, and Table 4 show that as follows:

1. The average value of respondents' responses to lecturer productivity is 3.43 . Based on the range of class scales this number is in the interval 3.41 - 4.20 with high / good assessment criteria.

2. The average value of the latent variable Transformational Leadership Style is 3.30. which are in the class range 2.61 - 3.40. From the results of the assessment can be interpreted that the average respondent gave a neutral answer or a pretty good assessment of this latent variable.

3. The average value of the latent variable of Communication is 3.37. which are in the class range 2.61 - 3.40. From the results of the assessment can be interpreted that the average respondent gave a neutral answer or a pretty good assessment of this latent variable.

Table 2: Description Data of Latent Variable (Productivity or Y)

\begin{tabular}{|c|l|r|r|r|r|r|r|}
\hline \multicolumn{1}{|c|}{ Construct } & N & $\begin{array}{r}\text { Mea } \\
\mathbf{n}\end{array}$ & St.Dev & Var & $\begin{array}{r}\text { Ma } \\
\mathbf{x}\end{array}$ & $\begin{array}{r}\text { Mi } \\
\mathbf{n}\end{array}$ \\
\hline $\mathrm{Y}_{1 .}$ & Number of research plans drawn up & 310 & 3.57 & .97 & .95 & & 1 \\
\hline $\mathrm{Y}_{2}$ & Number of problem statements identified & 310 & 3.48 & .90 & .80 & 5 & 1 \\
\hline $\mathrm{Y}_{3}$ & $\begin{array}{l}\text { Number of research proposals successfully } \\
\text { written }\end{array}$ & 310 & 3.50 & .95 & .90 & 5 & 1 \\
\hline
\end{tabular}




\begin{tabular}{|c|c|c|c|c|c|c|c|}
\hline & Construct & $\mathbf{N}$ & $\begin{array}{r}\text { Mea } \\
\mathbf{n}\end{array}$ & St.Dev & Var & $\begin{array}{r}\text { Ma } \\
\mathbf{x}\end{array}$ & $\begin{array}{r}\text { Mi } \\
\text { n }\end{array}$ \\
\hline $\mathrm{Y}_{4}$ & $\begin{array}{l}\text { Number of research proposals that are } \\
\text { followed up with research }\end{array}$ & 310 & 3.43 & .98 & .97 & 5 & 1 \\
\hline $\mathrm{Y}_{5}$ & Number of research reports written & 310 & 3.46 & .89 & .79 & 5 & 1 \\
\hline $\mathrm{Y}_{6}$ & $\begin{array}{l}\text { The number of articles successfully written } \\
\text { from the results of the study }\end{array}$ & 310 & 3.40 & .93 & .87 & 5 & 1 \\
\hline $\mathrm{Y}_{7}$ & $\begin{array}{l}\text { Number of articles successfully published } \\
\text { in reputable journals (domestic / foreign) }\end{array}$ & 310 & 3.27 & .95 & .90 & 5 & 1 \\
\hline $\mathrm{Y}_{8}$ & $\begin{array}{l}\text { Number of articles accepted as } \\
\text { international journals indexed by Scopus }\end{array}$ & 310 & 3.32 & .92 & .85 & 5 & 1 \\
\hline $\mathrm{Y}_{9}$ & $\begin{array}{l}\text { Number of articles successfully published } \\
\text { as Scopus indexed international journals }\end{array}$ & 310 & 3.35 & .92 & .84 & 5 & 1 \\
\hline $\mathrm{Y}_{10}$ & $\begin{array}{l}\text { Number of individual research results cited } \\
\text { / cited by others as a source of information }\end{array}$ & 310 & 3.52 & .94 & .88 & 5 & 1 \\
\hline$Y_{11}$ & $\begin{array}{l}\text { The number of results of individual studies } \\
\text { cited as a literature review }\end{array}$ & 310 & 3.50 & .93 & .87 & 5 & 1 \\
\hline $\mathrm{Y}_{12}$ & $\begin{array}{l}\text { Number of individual studies cited by } \\
\text { others for bibliometric evaluation }\end{array}$ & 310 & 3.46 & .90 & .81 & 5 & 1 \\
\hline$Y_{13}$ & $\begin{array}{l}\text { Number of results of individual studies } \\
\text { cited / quoted by others as historical } \\
\text { studies. }\end{array}$ & 310 & 3.31 & 1.01 & $\begin{array}{r}1.0 \\
3\end{array}$ & 5 & 1 \\
\hline$Y_{14}$ & $\begin{array}{l}\text { Number of individual research results cited } \\
\text { by others as information retrieval }\end{array}$ & 310 & 3.53 & .92 & .84 & 5 & 1 \\
\hline$Y_{15}$ & $\begin{array}{l}\text { Number of individual research results used } \\
\text { as books }\end{array}$ & 310 & 3.35 & .90 & .81 & 5 & 1 \\
\hline$Y_{16}$ & $\begin{array}{l}\text { Number of individual research results used } \\
\text { as reference books }\end{array}$ & 310 & 3.52 & .98 & .96 & 5 & 1 \\
\hline$Y_{17}$ & $\begin{array}{l}\text { Number of individual research results used } \\
\text { as dictates }\end{array}$ & 310 & 3.51 & .99 & .99 & 5 & 1 \\
\hline $\mathrm{Y}_{18}$ & $\begin{array}{l}\text { Number of individual research results that } \\
\text { were disseminated to the study program }\end{array}$ & 310 & 3.34 & .96 & .92 & 5 & 1 \\
\hline$Y_{19}$ & $\begin{array}{l}\text { The number of individual research results } \\
\text { that were disseminated within the Faculty }\end{array}$ & 310 & 3.43 & 1.03 & $\begin{array}{r}1.0 \\
6\end{array}$ & 5 & 1 \\
\hline $\mathrm{Y}_{20}$ & $\begin{array}{l}\text { Number of individual research results that } \\
\text { were disseminated at the University level }\end{array}$ & 310 & 3.32 & .95 & .91 & 5 & 1 \\
\hline$Y_{21}$ & $\begin{array}{l}\text { Number of individual research results } \\
\text { disseminated at the National level }\end{array}$ & 310 & 3.43 & .98 & .95 & 5 & 1 \\
\hline $\mathrm{Y}_{22}$ & $\begin{array}{l}\text { The number of individual research results } \\
\text { that were disseminated at the international } \\
\text { level }\end{array}$ & 310 & 3.39 & 1.00 & .99 & 5 & 1 \\
\hline $\mathrm{Y}_{23}$ & $\begin{array}{l}\text { Number of individual research results that } \\
\text { are followed up by other researchers for } \\
\text { more in-depth research }\end{array}$ & 310 & 3.39 & .99 & .97 & 5 & 1 \\
\hline
\end{tabular}




\begin{tabular}{|c|c|c|c|c|c|c|c|}
\hline & Construct & $\mathbf{N}$ & $\begin{array}{r}\text { Mea } \\
\mathbf{n}\end{array}$ & St.Dev & Var & $\begin{array}{r}\text { Ma } \\
\text { x }\end{array}$ & $\begin{array}{r}\text { Mi } \\
\mathbf{n}\end{array}$ \\
\hline $\mathrm{Y}_{24}$ & $\begin{array}{l}\text { The number of individual research results } \\
\text { that are followed up by other researchers in } \\
\text { the applied field }\end{array}$ & 310 & 3.40 & 1.01 & $\begin{array}{r}1.0 \\
1\end{array}$ & 5 & 1 \\
\hline $\mathrm{Y}_{25}$ & $\begin{array}{l}\text { Number of individual research results that } \\
\text { are followed up by other researchers as a } \\
\text { process of accumulating new findings / } \\
\text { theories }\end{array}$ & 310 & 3.50 & 1.02 & $\begin{array}{r}1.0 \\
5\end{array}$ & 5 & 1 \\
\hline & Y average & & 3.43 & .92 & .85 & 5 & 1 \\
\hline
\end{tabular}

Source: Processed from research results

Table 3: Description Data of Latent Variable (Transformational Leadership Style or X1)

\begin{tabular}{|c|c|c|c|c|c|c|c|}
\hline & Construct & $\mathbf{N}$ & Mean & $\begin{array}{l}\text { StdDe } \\
\mathbf{v}\end{array}$ & Var & $\begin{array}{l}\text { Ma } \\
\mathbf{x}\end{array}$ & $\begin{array}{l}\text { Mi } \\
\text { n }\end{array}$ \\
\hline $\mathrm{X}_{1 \cdot 1}$ & $\begin{array}{l}\text { The Head of Study Program gives } \\
\text { examples of research results which are } \\
\text { published in international journals }\end{array}$ & 310 & 3.29 & .97 & .94 & 5 & 1 \\
\hline$X_{1 \cdot 2}$ & $\begin{array}{l}\text { The Head of Study Program proposes to } \\
\text { compile a research proposal related to the } \\
\text { practical development of science in the } \\
\text { Study Program }\end{array}$ & 310 & 3.33 & .93 & .87 & 5 & 1 \\
\hline $\mathrm{X}_{1.3}$ & $\begin{array}{l}\text { Head of study program can create a sense } \\
\text { of calm in the face of difficulties in } \\
\text { research and publication of scopus indexed } \\
\text { scientific papers }\end{array}$ & 310 & 3.25 & .97 & .94 & 5 & 1 \\
\hline$X_{1 \cdot 4}$ & $\begin{array}{l}\text { Head of study program can find new } \\
\text { solutions to face difficulties in research / } \\
\text { publication of scientific papers indexed } \\
\text { Scopus }\end{array}$ & 310 & 3.29 & .88 & .78 & 5 & 1 \\
\hline$X_{1 . .5}$ & $\begin{array}{l}\text { Head of Study Program gives positive } \\
\text { support to research and publication of } \\
\text { scientific papers through scheduled \& } \\
\text { continuous research clinics }\end{array}$ & 310 & 3.30 & .90 & .81 & 5 & 1 \\
\hline$X_{1.6}$ & $\begin{array}{l}\text { Head of Study Program provides facilities } \\
\text { to conduct research \& publication of } \\
\text { scientific papers in reputable journals }\end{array}$ & 310 & 3.29 & .93 & .87 & 5 & 1 \\
\hline$X_{1 \cdot 7}$ & $\begin{array}{l}\text { The Head of Study Program always puts } \\
\text { forward a good attitude to encourage } \\
\text { lecturers to be active in research and } \\
\text { publication of international scientific works } \\
\text { in reputable journals. }\end{array}$ & 310 & 3.37 & .94 & .88 & 5 & 1 \\
\hline$X_{1 \cdot 8}$ & $\begin{array}{l}\text { The Head of Study Program behaves } \\
\text { wisely in facing difficulties faced by } \\
\text { lecturers in research / publication of } \\
\text { scientific papers in scopus indexed journals }\end{array}$ & 310 & 3.23 & .90 & .81 & 5 & 1 \\
\hline
\end{tabular}




\begin{tabular}{|c|c|c|c|c|c|c|c|}
\hline & Construct & $\mathbf{N}$ & Mean & $\begin{array}{l}\text { StdDe } \\
\mathbf{v}\end{array}$ & Var & $\begin{array}{l}\text { Ma } \\
\text { x } \\
\end{array}$ & $\begin{array}{l}\text { Mi } \\
\text { n }\end{array}$ \\
\hline$X_{1 \cdot 9}$ & $\begin{array}{l}\text { The Head of Study Program can be a role } \\
\text { model because he is active in research and } \\
\text { publication of international scientific } \\
\text { papers in reputable journals }\end{array}$ & 310 & 3.32 & .96 & .92 & 5 & 1 \\
\hline$X_{1 \cdot 10}$ & $\begin{array}{l}\text { Head of Study Program gives enthusiasm } \\
\text { to lecturers in research \& publication of } \\
\text { scientific papers through active } \\
\text { participation in research clinics }\end{array}$ & 310 & 3.25 & 1.00 & $\begin{array}{l}1.0 \\
0\end{array}$ & 5 & 1 \\
\hline$X_{1 \cdot 11}$ & $\begin{array}{l}\text { Head of Study Program can foster lecturer } \\
\text { creativity in overcoming problems in } \\
\text { research and publication of scientific } \\
\text { papers. }\end{array}$ & 310 & 3.32 & .94 & .89 & 5 & 1 \\
\hline$X_{1 \cdot 12}$ & $\begin{array}{l}\text { Head of Study Program understands the } \\
\text { direction / goals of universities in the field } \\
\text { of research and publications in reputable } \\
\text { scientific papers }\end{array}$ & 310 & 3.30 & .89 & .80 & 5 & 1 \\
\hline$X_{1.13}$ & $\begin{array}{l}\text { The Head of Study Program implanted the } \\
\text { meaning of Tridharma Perguruan Tinggi } \\
\text { and in research and publication of scientific } \\
\text { works. }\end{array}$ & 310 & 3.38 & .98 & .95 & 5 & 1 \\
\hline$X_{1 \cdot 14}$ & $\begin{array}{l}\text { The Head of Study Program provides an } \\
\text { opportunity to solve problems encountered } \\
\text { in research and publication of scientific } \\
\text { papers in their own way }\end{array}$ & 310 & 3.31 & .90 & .82 & 5 & 1 \\
\hline$X_{1 \cdot 15}$ & $\begin{array}{l}\text { The Head of Study Program inspires } \\
\text { lecturers' work in the field of research and } \\
\text { publication of international scientific } \\
\text { papers through the research clinic program }\end{array}$ & 310 & 3.33 & .92 & .85 & 5 & 1 \\
\hline \multirow[t]{2}{*}{$X_{1 \cdot 16}$} & $\begin{array}{l}\text { The Head of Study Program encourages } \\
\text { lecturers to be more creative in research } \\
\text { and publication of scientific papers in } \\
\text { reputable journals }\end{array}$ & 310 & 3.29 & .94 & .89 & 5 & 1 \\
\hline & $\mathrm{X} 1$ average & & 3.30 & .93 & .88 & 5 & 1 \\
\hline
\end{tabular}

Source: Processed from research results

Table 4: Description Data of Latent Variable (Communication or X2)

\begin{tabular}{|l|l|l|l|l|l|l|l|l|}
\hline & Construct & \multicolumn{1}{|c|}{$\mathbf{N}$} & Mean & StDev & Var & Max & Min \\
\hline $\mathrm{X}_{21}$. & $\begin{array}{l}\text { The Head of Study Program communicates } \\
\text { the importance of conducting research and } \\
\text { publications of reputable international } \\
\text { scientific papers }\end{array}$ & 310 & 3.32 & .95 & .90 & 5 & 1 \\
\hline
\end{tabular}




\begin{tabular}{|c|c|c|c|c|c|c|c|}
\hline & Construct & $\mathbf{N}$ & Mean & StDev & Var & Max & Min \\
\hline $\mathrm{X}_{2.2 .}$ & $\begin{array}{l}\text { Openness of communication with the Head } \\
\text { of Study Program in research activities and } \\
\text { publication of reputable international } \\
\text { scientific papers }\end{array}$ & 310 & 3.31 & .92 & .85 & 5 & 1 \\
\hline $\mathrm{X}_{2.3 .}$ & $\begin{array}{l}\text { Openness of communication among } \\
\text { lecturers in research activities / } \\
\text { publications of reputed international } \\
\text { scientific papers }\end{array}$ & 310 & 3.42 & .88 & .77 & 5 & 1 \\
\hline $\mathrm{X}_{2.4}$ & $\begin{array}{l}\text { Openness to express opinions in meetings } \\
\text { with the Head of Study Program }\end{array}$ & 310 & 3.33 & .93 & .86 & 5 & 1 \\
\hline$X_{2.5}$ & $\begin{array}{l}\text { Receive and apply the results of meeting } \\
\text { resolutions to overcome problems in } \\
\text { research and publication of scientific } \\
\text { papers }\end{array}$ & 310 & 3.38 & .98 & .95 & 5 & 1 \\
\hline $\mathrm{X}_{2.6}$ & $\begin{array}{l}\text { Carry out an agreement on the results of a } \\
\text { meeting with colleagues in conducting } \\
\text { research activities and publication of } \\
\text { scientific papers }\end{array}$ & 310 & 3.41 & .91 & .83 & 5 & 1 \\
\hline$X_{2.7}$ & $\begin{array}{l}\text { Listen carefully to the ideas, opinions and } \\
\text { opinions of the Head of Study Program } \\
\text { related to research and publication of } \\
\text { scientific papers }\end{array}$ & 310 & 3.26 & 1.01 & 1.03 & 5 & 1 \\
\hline $\mathrm{X}_{2.8}$ & $\begin{array}{l}\text { Colleagues convey ideas, ideas, and } \\
\text { opinions related to research and } \\
\text { publications in internationally reputable } \\
\text { scientific papers }\end{array}$ & 310 & 3.41 & .88 & .78 & 5 & 1 \\
\hline$X_{2.9}$ & $\begin{array}{l}\text { The information conveyed by the Head of } \\
\text { Study Program made me an important part } \\
\text { in conducting research / publication of } \\
\text { scientific papers }\end{array}$ & f 310 & 3.29 & .99 & .98 & 5 & 1 \\
\hline $\mathrm{X}_{2.10}$ & $\begin{array}{l}\text { Head of Study Program explained about } \\
\text { the importance of attending research } \\
\text { clinics organized by the Faculty }\end{array}$ & 310 & 3.30 & .95 & .90 & 5 & 1 \\
\hline$X_{2.11}$ & $\begin{array}{l}\text { The Head of Study Program considers the } \\
\text { ability of each lecturer in researching and } \\
\text { writing international scientific works when } \\
\text { attending research clinics }\end{array}$ & 310 & 3.42 & .96 & .92 & 5 & 1 \\
\hline$X_{2 \cdot 12}$ & $\begin{array}{l}\text { Be positive when receiving conflicting } \\
\text { criticisms / input in conducting research / } \\
\text { writing / publication of scientific papers }\end{array}$ & 310 & 3.47 & .89 & .80 & 5 & 1 \\
\hline $\mathrm{X}_{2 \cdot 13}$ & $\begin{array}{l}\text { Opportunities to ask questions and respond } \\
\text { to research clinic activities are very limited }\end{array}$ & 310 & 3.38 & .95 & .90 & 5 & 1 \\
\hline $\mathrm{X}_{2 \cdot 14}$ & $\begin{array}{l}\text { Head of Study Program is positive when } \\
\text { accepting criticism or ideas that are not } \\
\text { supportive }\end{array}$ & 310 & 3.41 & .91 & .83 & 5 & 1 \\
\hline
\end{tabular}




\begin{tabular}{|c|c|c|c|c|c|c|c|}
\hline & Construct & $\mathbf{N}$ & Mean & StDev & Var & Max & Min \\
\hline $\mathrm{X}_{2.15}$ & $\begin{array}{l}\text { There are similarities in values, attitudes, } \\
\text { behavior and experience in communicating } \\
\text { to conduct research / publications in } \\
\text { reputed international scientific papers }\end{array}$ & \begin{tabular}{l|l} 
& 310 \\
$\mathrm{~g}$ &
\end{tabular} & 3.38 & .93 & .87 & 5 & 1 \\
\hline$X_{2.16}$ & $\begin{array}{l}\text { Apply the same values and do not } \\
\text { dominate communication }\end{array}$ & 310 & 3.42 & .95 & .90 & 5 & 1 \\
\hline \multirow[t]{2}{*}{$\mathrm{X}_{2.17}$} & $\begin{array}{l}\text { Fellow lecturers like to do research that is } \\
\text { done together }\end{array}$ & 310 & 3.36 & .97 & .94 & 5 & 1 \\
\hline & $\mathrm{X} 2$ average & & 3,37 & .94 & .88 & 5 & 1 \\
\hline
\end{tabular}

Source: Processed from research results

\section{The Important of Lecturer Productivity Factors, Transformational Leadership Styles and Communication at Private Universities.}

From Table 2, the results of the descriptive statistical assessment revealed that the majority of respondents stated that the productivity of lecturers in producing reputable scientific works was already relatively high / good. The highest value of the assessment is in the construct Y1, namely the number of research plans drawn up in connection with the writing of international scientific work. While the lowest value on the Y7 construct is the number of articles successfully published in reputable journals at home / abroad; Whereas from table 3, the results of the descriptive statistical assessment revealed that the results of this assessment could be interpreted as respondents agree that the leadership style applied at the three private universities which were the objects of this study were quite good. The highest value is in the X1.13 construct, namely the Head of Study Program implements the Tridharma of Higher Education and implements it in conducting research and publication of international scientific papers in reputable journals. While the lowest value in construct X1.8 is Head of Study Program behaves wisely in facing difficulties of lecturers in conducting research and publication of scientific papers in reputable / indexed scopus journals. Then, from table 4, the results of the descriptive statistical assessment revealed that the results of this assessment could be interpreted that the respondents agreed that the communication applied was good enough. The highest score is in construct X2.12 with a value of 3.47, namely the Head of Study Program is positive when accepting conflicting criticisms and input in conducting research and publication of reputable international scientific works. While the lowest value in construct X2.7 with a value of 3.26 is listening carefully to every idea / idea / opinion submitted by the Head of Study Program to improve the quality of research and publication of scientific papers.

\section{Results and Discussion}

\section{Leadership Style Variables (X1)}

Based on the test results of the measurement model for the latent variables of the Transformational Leadership Style (X1) in Table 5 there are some observable / construct variables that have been excluded from the measurement model because they have a standardized loading factor value $<0.50$. Of the 16 observable variables / constructs of latent variables Transformational Leadership Style (X1) there are only 7 (seven) valid observed / construct variables $(\mathrm{SLF} \geq 0.50)$ and can be used in the measurement model. Furthermore, the results of the fit test of the CFA model of latent variables in the Transformational Leadership Style (X1) show that most of the fit criteria are in the good fit category. Thus it can be concluded that the CFA goodnest of fit test of the Transformational Leadership Style (X1) variable model is acceptable because there is no significant difference between the covariance matrix of the observed / construct variable data and the covariance matrix of the model specified. This shows that the measurement equation produced by the research model can be used to explain the measured variable. 
Table 5: Standardized Loading Factor Leadership Variable Transformational (X1)

\begin{tabular}{|c|c|c|c|c|c|}
\hline $\begin{array}{l}\text { Construct } \\
\text { Variable }\end{array}$ & & Latent Variable & $\begin{array}{c}\text { Standardized } \\
\text { Loading } \\
\text { Factor }\end{array}$ & $\begin{array}{c}\text { Construct } \\
\text { Reliability } \\
\text { (CR) }\end{array}$ & $\begin{array}{c}\text { Average } \\
\text { Variance } \\
\text { Extracted } \\
\text { (AVE) }\end{array}$ \\
\hline X.1,3 & $<---$ & $\begin{array}{c}\text { Transformational } \\
\text { Leadership Style_X1 }\end{array}$ & 0,749 & \multirow{7}{*}{0,906} & \multirow{7}{*}{0,581} \\
\hline $\mathrm{X} 1.7$ & $<---$ & $\begin{array}{c}\text { Transformational } \\
\text { Leadership Style _ X1 }\end{array}$ & 0,751 & & \\
\hline $\mathrm{X} 1.10$ & $<---$ & $\begin{array}{c}\text { Transformational } \\
\text { Leadership Style _ X1 }\end{array}$ & 0,796 & & \\
\hline $\mathrm{X} 1 . .11$ & $<---$ & $\begin{array}{c}\text { Transformational } \\
\text { Leadership Style__ X1 }\end{array}$ & 0,797 & & \\
\hline $\mathrm{X} 1 . .12$ & $<---$ & $\begin{array}{c}\text { Transformational } \\
\text { Leadership Style _ X1 }\end{array}$ & 0,778 & & \\
\hline $\mathrm{X} 1.13$ & $<---$ & $\begin{array}{c}\text { Transformational } \\
\text { Leadership Style _ X1 }\end{array}$ & 0,688 & & \\
\hline $\mathrm{X} 1.14$ & $<---$ & $\begin{array}{c}\text { Transformational } \\
\text { Leadership Style _ X1 }\end{array}$ & 0,769 & & \\
\hline
\end{tabular}

$\boldsymbol{S L F}=$ Standardized Loading Factor, good SLF value $\geq 0.50$

$\boldsymbol{C R}=$ Construct Reliability, good CR value $\geq 0.70$

$\boldsymbol{A} \boldsymbol{V E}=$ Variance Extracted, good AVE value $\geq 0.50$

The results of testing the measurement model on the Transformational Leadership Style (X1) variable, all observed / construct variables meet the validity requirements as measuring variables forming latent variables because they have a standard loading value $\geq 0.50$. The observed variable / construct that has the highest factor loading value is the observed / construct variable of the Head of Department. lowest loading is the observable variable / construct of Head of Study Program instilling the meaning of Higher Education Tridharma and implementing it in conducting research and publication of scientific papers (X1.13) with a factor loading value of 0.688. Furthermore, the reliability test results for the latent variables of the Transformational Leadership Style (X1) show good reliability. This can be seen from the value of Construct Reliability (CR) and Average Variance Extracted (AVE) which is greater than the minimum provisions, namely CR $(0.906 \geq 0.70)$ and AVE $(0.581 \geq 0.50)$.

Model fit test on the CFA model or Goodnest of fit aims to measure the suitability of the research data with the research model in other words measure the suitability of observational or actual inputs (covariance / correlation matrix) with the proposed model predictions. Based on table 4.15 The fit output of the CFA model fit test of latent variables in the Transformational Leadership Style (X1) most of the fit criteria in the good fit category. Latan (2012: 49) states that 4 - 5 goodnest of fit criteria are considered sufficient to assess the feasibility of a model, provided that each criterion of goodnest of fit is absolute fit indices, incremental fit indices and parsimony indices are represented. Thus it can be concluded that the CFA goodnest of fit test of the Transformational Leadership Style (X1) variable model can be accepted in other words there is no 
significant difference between the covariance matrix of observed / construct variable data with the covariance matrix of the specified model. This shows that the measurement equation produced by the research model can be used to explain the measured variable.

Table 6: CFA Model Match Test Results Transformational Leadership Style Latent Variable (X1)

\begin{tabular}{|l|l|l|l|}
\hline Absolut Fit Measure & Cut-off Value & Hasil & Kecocokan \\
\hline Goodness-of-Fit & \multicolumn{1}{|l|}{$>0,05$} & 0,251 & Good fit \\
\hline p-value (Sig.) & $\leq 3$ & 1,222 & Good fit \\
\hline Chi-Square/df & $\geq 0,90$ & 0,985 & Good Fit \\
\hline GFI(Goodness of Fit) & $\leq 0,08$ & 0,027 & Good Fit \\
\hline RMSEA(Root Mean square Error of Approximation) & $\leq 0,05$ & 0,017 & Good Fit \\
\hline RMR(Root Mean Square Residual) & \multicolumn{5}{l|}{} \\
\hline Incremental Fit Measure & Cut-off Value & Hasil & Kecocokan \\
\hline Goodness-of-Fit & $\geq 0,90$ & 0,969 & Good Fit $t$ \\
\hline AGFI(Adjusted Goodness of Fit Index) & $\geq 0,90$ & 0,977 & Good Fit \\
\hline CFI (Comparative Fit Index) & $\geq 0,90$ & 0,977 & Good Fit \\
\hline Incremental Fit Index (IFI) & $\geq 0,95$ & 0,978 & Good Fit \\
\hline Relative Fit Index (RFI) & \multicolumn{5}{l|}{} \\
\hline Parsimonious Fit Measure & Harus kecil & 0,657 & Good Fit \\
\hline PNFI (Parsimonious Normed Fit Index) & Mendekati 1 & 0,492 & Good fit \\
\hline PGFI (Parsimonious Goodness Of Fit Index) & $<56,000$ & 45,107 & Good Fit \\
\hline AIC (Akaike Information Criterion) & $<188,624$ & 111,419 & Good Fit \\
\hline CAIC (Consistent Akaike Information Criterion) &
\end{tabular}

\section{Communication Variable (X2)}

Based on the test results of the measurement model for the latent variable of Communication (X2) in Table 7 shows that out of 17 observed variables / constructs there are only 8 (eight) valid variables (SLF $\geq 0.50)$ to be used in the measurement model. In addition, the results of the fit test of the CFA model on this latent variable showed most of the criteria of the fit model in the good fit category. Thus it can be concluded that the CFA goodnest of fit test of the Communication variable model (X2) is acceptable because there is no significant difference between the observed / construct variable data covariance matrix and the covariance matrix of the model specified. This shows that the measurement equation produced by the research model can be used to explain the measured variable.

Table 7: Standardized Loading Factor Recpecification Model Confirmatory Factor Analysis Variable Communication (X2)

\begin{tabular}{|c|c|c|c|c|c|}
\hline $\begin{array}{l}\text { Construct } \\
\text { Variable }\end{array}$ & & Latent Variable & $\begin{array}{l}\text { Standardized } \\
\text { Loading } \\
\text { Factor }\end{array}$ & $\begin{array}{l}\text { Construct } \\
\text { Reliability } \\
\text { (CR) }\end{array}$ & $\begin{array}{l}\text { Average } \\
\text { Variance } \\
\text { Extracted } \\
(\text { AVE) } \\
\end{array}$ \\
\hline $\mathrm{X} 2.1$ & $<---$ & Communication_X2 & 0,571 & \multirow[t]{8}{*}{0,901} & \multirow[t]{8}{*}{0,535} \\
\hline $\mathrm{X} 2.3$ & $<---$ & Communication_X2 & 0,692 & & \\
\hline $\mathrm{X} 2.5$ & $<---$ & Communication_X2 & 0,780 & & \\
\hline $\mathrm{X} 2.6$ & $<--$ & Communication_X2 & 0,785 & & \\
\hline $\mathrm{X} 2.8$ & $<--$ & Communication _ X2 & 0,776 & & \\
\hline $\mathrm{X} 2.12$ & $<---$ & Communication_X2 & 0,755 & & \\
\hline $\mathrm{X} 2.13$ & $<---$ & Communication _ $\mathrm{X} 2$ & 0,740 & & \\
\hline $\mathrm{X} 2.15$ & $<---$ & Communication_X $\mathrm{X} 2$ & 0,731 & & \\
\hline
\end{tabular}


SLF $=$ Standardized Loading Factor, good SLF value $\geq 0.50$

$\boldsymbol{C R}=$ Construct Reliability, good $C R$ value $\geq 0.70$

$\boldsymbol{A} \boldsymbol{V E}=$ Variance Extracted, good AVE value $\geq 0.50$

The results of testing the measurement model for latent variables Communication (X2) shows that all observed / construct variables have met the validity requirements where the standard loading factor is $\geq$ 0.50 . The value of construct reability (CR) $0.901 \geq 0.70$ and average variance extracted (AVE) $0.535 \geq 0.50$ indicate that all observed / construct variables that measure latent variables Communication (X2) has a good enough reliability to be used as a variable measurement / variable forming latent. The observed variable / construct which has the highest loading factor value is the observed / construct variable Running the agreement on the results of a joint meeting with colleagues (X2.6) with a loading factor value of 0.785 , while the observed / construct variable that has the lowest loading factor is the observed variable / construct Openness of communication with the Head of Study Program.

Furthermore, to measure the suitability of the research data with the research model or measure the suitability of the observational input (covariance / correlation matrix) with the proposed model prediction, the model fit will be tested on the CFA model or Goodnest of fit. The fit test results of the CFA (Goodness of Fit Test) model can be seen in the following table 8:

Table 8: Test Match of the CFA Model of Communication Variables (X2)

\begin{tabular}{|l|l|l|l|}
\hline Absolut Fit Measure & Cut-off Value & Result & Goodness of fit test \\
\hline Goodness-of-Fit & \multicolumn{1}{|l|}{$>0,05$} & 0,157 & Good fit \\
\hline p-value (Sig.) & $\leq 3$ & 1,313 & Good fit \\
\hline Chi-Square/df & $\geq 0,90$ & 0,978 & Good Fit \\
\hline GFI(Goodness of Fit) & $\leq 0,08$ & 0,032 & Good Fit \\
\hline RMSEA(Root Mean square Error of Approximation) & $\leq 0,05$ & 0,018 & Good Fit \\
\hline RMR(Root Mean Square Residual) & \multicolumn{5}{|l|}{} \\
\hline Incremental Fit Measure & Cut-offValue & Result & Goodness of fit test \\
\hline Goodness-of-Fit & $\geq 0,90$ & 0,961 & Good Fit $t$ \\
\hline AGFI(Adjusted Goodness of Fit Index) & $\geq 0,90$ & 0,995 & Good Fit \\
\hline CFI (Comparative Fit Index) & $\geq 0,90$ & 0,995 & Good Fit \\
\hline Incremental Fit Index (IFI) & $\geq 0,95$ & 0,970 & Good Fit \\
\hline Relative Fit Index (RFI) & \multicolumn{5}{l|}{} \\
\hline Parsimonious Fit Measure & Must be smaller than & 0,699 & Good Fit \\
\hline PNFI (Parsimonious Normed Fit Index) & Must Approach 1 & 0,544 & Good fit \\
\hline PGFI (Parsimonious Goodness Of Fit Index) & $<72,000$ & 58,257 & Good Fit \\
\hline AIC (Akaike Information Criterion) & $<242,517$ & 134,042 & Good Fit \\
\hline CAIC (Consistent Akaike Information Criterion) & \multicolumn{4}{l}{} \\
\hline
\end{tabular}

\section{Productivity Variable (Y)}

The results of testing the measurement model based on the value of the standardized loading factor in each construct of latent variables Productivity (Y) there are only 10 valid observed/construct variables (standardized loading factor $\geq 0.50$ ) are as follows. Based on the results of the Fit Test of the CFA Model of the Latent Variable of Communication (X2), most of the fit criteria are in the good fit category. According to Latan (2012: 49), the fulfillment of 4-5 goodnest of fit criteria is considered sufficient to assess the feasibility of a model, provided that each criterion of goodnest of fit is absolute fit indices, incremental fit indices and parsimony indices are represented. Thus it can be concluded that the CFA goodnest of fit test of the latent model of Communication (X2) can be accepted in other words there is no significant difference between the covariance matrix of the observed / construct variable data with the covariance matrix of the model that has been specified. This shows that the measurement equation produced by the research model can be used to explain the measured variable. 
Table 9: Standardized Loading Factor Respisification Model Confirmatory Factor Analysis Latent Productivity (Y)

\begin{tabular}{|c|c|c|c|c|c|}
\hline $\begin{array}{l}\text { Construct } \\
\text { Variable }\end{array}$ & & Latent Variable & $\begin{array}{l}\text { Standardized } \\
\text { Loading } \\
\text { Factor }\end{array}$ & $\begin{array}{l}\text { Construct } \\
\text { Reliability } \\
\text { (CR) }\end{array}$ & $\begin{array}{l}\text { Average } \\
\text { Variance } \\
\text { Extracted } \\
\text { (AVE) } \\
\end{array}$ \\
\hline $\mathrm{Y}_{1}$ & $<--$ & Productivity_Y & 0,790 & \multirow{10}{*}{0,954} & \multirow{10}{*}{0,677} \\
\hline$Y_{5}$ & $<--$ & Productivity_Y & 0,839 & & \\
\hline $\mathrm{Y}_{10}$ & $<--$ & Productivity_Y & 0,851 & & \\
\hline$Y_{11}$ & $<---$ & Productivity_Y & 0,816 & & \\
\hline $\mathrm{Y}_{12}$ & $<--$ & Productivity_Y & 0,844 & & \\
\hline $\mathrm{Y}_{14}$ & $<--$ & Productivity_Y & 0,837 & & \\
\hline$Y_{16}$ & $<--$ & Productivity_Y & 0,783 & & \\
\hline$Y_{17}$ & $<--$ & Productivity_Y & 0,831 & & \\
\hline$Y_{21}$ & $<---$ & Productivity_Y & 0,836 & & \\
\hline $\mathrm{Y}_{23}$ & <--- & Productivity_Y & 0,798 & & \\
\hline
\end{tabular}

$\boldsymbol{S L F}=$ Standardized Loading Factor, good SLF value $\geq 0.50$

$\boldsymbol{C R}=$ Construct Reliability, good CR value $\geq 0.70$

$\boldsymbol{A} \boldsymbol{V E}=$ Variance Extracted, good AVE value $\geq 0.50$

The results of testing the measurement model for latency variables Productivity (Y) in Table 9 shows that all observed / construct variables have fulfilled the requirements to be used as measuring variables / forming latent variables because they have a loading standard value $\geq 0.50$. This result concludes that all observable / construct variables are valid and can be used to measure or form latent variables. The observed / construct variable that has the highest value is the observed / construct variable Y10. The number of individual research results cited / cited by others as a source of information has a loading factor value of 0.851 . While the observed / construct variable that has the lowest value is the observed / construct variable Y16, the number of individual research results used as a Reference Book with a loading factor value of 0.783. Furthermore, the reliability test results for the latent variable Productivity (Y) also showed quite good results. Construct reliability (CR) and Average Variance Extracted (AVE) values are above the minimum value provisions namely Construct Reliability $(0.954 \geq 0.70)$ and Average Variance Extracted $(0.677 \geq$ 0.50). Therefore it can be concluded that all observed / construct variables that measure / form latent variables Productivity (Y) have a pretty good reliability.

To measure the suitability of the research data with the research model or in other words to measure the suitability of the observational input (covariance / correlation matrix) with the prediction of the proposed model can be seen in the results of the fit test of the CFA model. The fit test results of the CFA model can be seen in table 4.24 as follows:

Table 10: CFA Model Variable Productivity (Y) Match Test

\begin{tabular}{|l|l|l|l|}
\hline Absolut Fit Measure & Cut-off Value & Result & Goodness of fit test \\
\hline Goodness-of-Fit & \multicolumn{1}{|c|}{$>0,05$} & 0,739 & Good fit \\
\hline p-value (Sig.) & $\leq 3$ & 0,837 & Good fit \\
\hline Chi-Square/df & $\geq 0,90$ & 0,982 & Good Fit \\
\hline GFI(Goodness of Fit) & &
\end{tabular}




\begin{tabular}{|l|l|l|l|}
\hline Absolut Fit Measure & Cut-off Value & Result & Goodness of fit test \\
\hline Goodness-of-Fit & $\leq 0,08$ & 0,000 & Good Fit \\
\hline RMSEA(Root Mean square Error of Approximation) & $\leq 0,05$ & 0,013 & Good Fit \\
\hline RMR(Root Mean Square Residual) & \multicolumn{5}{l|}{} \\
\hline \multicolumn{3}{|l|}{} \\
Incremental Fit Measure & Cut-off Value & Result & Goodness of fit test \\
\hline Goodness-of-Fit & $\geq 0,90$ & 0,971 & Good Fit $t$ \\
\hline AGFI(Adjusted Goodness of Fit Index) & $\geq 0,90$ & 1,000 & Good Fit \\
\hline CFI (Comparative Fit Index) & $\geq 0,90$ & 1,002 & Good Fit \\
\hline Incremental Fit Index (IFI) & $\geq 0,95$ & 0,985 & Good Fit \\
\hline Relative Fit Index (RFI) & \multicolumn{3}{l|}{} \\
\hline Parsimonious Fit Measure & Must be smaller than & 0,769 & Good Fit \\
\hline PNFI (Parsimonious Normed Fit Index) & Must Approach 1 & 0,625 & Good fit \\
\hline PGFI (Parsimonious Goodness Of Fit Index) & $<110,000$ & 69,310 & Good Fit \\
\hline AIC (Akaike Information Criterion) & $<370,511$ & 164,041 & Good Fit \\
\hline CAIC (Consistent Akaike Information Criterion) &
\end{tabular}

Thus it can be concluded that the CFA Goodnest of fit test of the Productivity Variable Model (Y) can be accepted in other words there is no significant difference between the covariance matrix of the observed variable (construct) and the covariance matrix of the specified model. This shows that the measurement equation generated by the research model can be used to explain the measured variable.

\section{Goodness of fit (GOF) Struktural Equation Model}

Model suitability test is expected to accept the null hypothesis. In SEM the test is carried out using a number of Goodness of Fit Tests (GOF). Model fitness test or goodness of fit aims to measure the suitability of the research data with the research model in other words measure the suitability of observational or actual inputs (covariance / correlation matrix) with the proposed model predictions. Model fit test - Full Model SEM Model can be seen in the table 11 as follows:

\section{Table 11: Full Model SEM Model Match Tests}

\begin{tabular}{|c|c|c|c|}
\hline \multicolumn{4}{|l|}{ Absolut Fit Measure } \\
\hline Goodness-of-Fit & Cut-off Value & Result & $\begin{array}{l}\text { Goodness of fit } \\
\text { test }\end{array}$ \\
\hline p-value (Sig.) & $>0,05$ & 0,891 & Good fit \\
\hline Chi-Square/df & $\leq 3$ & 0,938 & Good fit \\
\hline GFI(Goodness of Fit) & $\geq 0,90$ & 0,901 & Good fit \\
\hline $\begin{array}{l}\mathrm{RMSEA}(\text { Root Mean square } \text { Error of } \\
\text { Approximation })\end{array}$ & $\leq 0,08$ & 0,000 & Good fit \\
\hline RMR(Root Mean Square Residual) & $\leq 0,05$ & 0,039 & Good fit \\
\hline \multicolumn{4}{|l|}{ Incremental Fit Measure } \\
\hline Goodness-of-Fit & Cut-off Value & Result & $\begin{array}{l}\text { Goodness of fit } \\
\text { test }\end{array}$ \\
\hline AGFI(Adjusted Goodness of Fit Index) & $\geq 0,90$ & 0,889 & Marginal fit \\
\hline CFI (Comparative Fit Index) & $\geq 0,90$ & 1,000 & Good fit \\
\hline Incremental Fit Index (IFI) & $\geq 0,90$ & 1,006 & Good fit \\
\hline Relative Fit Index (RFI) & $\geq 0,95$ & 0,913 & Margina; fit \\
\hline
\end{tabular}




\begin{tabular}{|c|c|c|c|}
\hline \multicolumn{4}{|l|}{ Absolut Fit Measure } \\
\hline Goodness-of-Fit & Cut-off Value & Result & $\begin{array}{l}\text { Goodness of fit } \\
\text { test }\end{array}$ \\
\hline \multicolumn{4}{|l|}{ Parsimonious Fit Measure } \\
\hline PNFI (Parsimonious Normed Fit Index) & $\begin{array}{l}\text { Must be smaller } \\
\text { than }\end{array}$ & 0,862 & Marginal fit \\
\hline PGFI (Parsimonious Goodness Of Fit Index) & Must Approach 1 & 0,806 & Good fit \\
\hline AIC (Akaike Information Criterion) & $<\underline{1722,000}$ & 903,954 & Good fit \\
\hline $\begin{array}{l}\text { CAIC ( Consistent Akaike Information } \\
\text { Criterion) }\end{array}$ & $<\underline{5800,189}$ & 1334,954 & Good fit \\
\hline
\end{tabular}

Based on the Full Model SEM Model Match Test output, most of the L model criteria are in the good fit category. While Latan (2012: 49) states that 4 - 5 goodness of fit criteria are considered to be sufficient to assess the feasibility of a model, provided that each criterion of goodness of fit namely absolute fit indices, incremental fit indices and parsimony indices are represented. Thus it can be concluded that the goodness of fit test of the full Model SEM model can be accepted in other words there is no significant difference between the covariance matrix of the observed variable data (construct) and the covariance matrix of the specified model. This shows that the structural equation produced by the research model can be used to explain the influence between exogenous variables and their endogenous variables.

\section{Full Structural Model (SEM) Full Test Results}

Based on the results of the full SEM model test results above, it can be seen that there are some observed variables or constructs that do not meet the requirements to be used in the calculation of the CFA model for each variable. If the criteria for goodness of fit in a research model are not met so that the model respesification is done by removing the observed / construct variable from the CFA model on each variable. The results of the re-verification of the research model can be seen in the following Amos output: To test the significance of the path coefficient the direct influence can be seen in the Path coefficient table and C.R. ( $\mathrm{t}$-value) below:

Table 12: Path coefficients and C.R. ( $\left.t_{\text {value }}\right)$

\begin{tabular}{|l|l|lr|l|l|l|l|l|}
\hline $\begin{array}{l}\text { Variabel } \\
\text { Laten Endogen }\end{array}$ & & $\begin{array}{l}\text { Variabel } \\
\text { Eksogen }\end{array}$ & Laten & $\begin{array}{l}\text { Std } \\
\text { Estimate }\end{array}$ & $\begin{array}{l}\text { Unstd } \\
\text { Estimate }\end{array}$ & S.E. & C.R. & P \\
\hline Productivity_Y & $<-$ & $\begin{array}{l}\text { Transformational } \\
\text { Style_X }\end{array}$ & Leadership & 0,201 & 0,206 & 0,056 & 3,715 & $* * *$ \\
\hline Productivity_Y & $<--$ & Communication_X & & 0,302 & 0,415 & 0,081 & 5,132 & $* * *$ \\
\hline
\end{tabular}

\section{Transformational Leadership Style_X1}

\begin{tabular}{|l|c|l|l|}
\hline Construct Variabel & & Laten Variabel & Loading Factor \\
\hline X1.3 & $<---$ & Transformational Leadership Style_X1 & 0,749 \\
\hline X1.7 & $<---$ & Transformational Leadership Style_X1 & 0,748 \\
\hline X1.10 & $<---$ & Transformational Leadership Style_X1 & 0,797 \\
\hline X1.11 & $<---$ & Transformational Leadership Style_X1 & 0,799 \\
\hline X1.12 & $<---$ & Transformational Leadership Style_X1 & 0,776 \\
\hline X1.13 & $<---$ & Transformational Leadership Style_X1 & 0,687 \\
\hline
\end{tabular}




\begin{tabular}{|l|l|l|l|}
\hline X1.14 & $<---$ & Transformational Leadership Style_X1 & 0,771 \\
\hline
\end{tabular}

Communication_X2

\begin{tabular}{|l|c|l|l|}
\hline Construct Variabel & & Laten Variabel & Loading Factor \\
\hline X2.1 & $<---$ & Communication_X2 & 0,572 \\
\hline X2.3 & $<---$ & Communication_X2 & 0,692 \\
\hline X2.5 & $<---$ & Communication_X2 & 0,783 \\
\hline X2.6 & $<---$ & Communication_X2 & 0,789 \\
\hline X2.8 & $<---$ & Communication_X2 & 0,778 \\
\hline X2.12 & $<---$ & Communication_X2 & 0,753 \\
\hline X2.13 & $<---$ & Communication_X2 & 0,736 \\
\hline X2.15 & $<---$ & Communication_X2 & 0,726 \\
\hline
\end{tabular}

Productivity_Y

\begin{tabular}{|l|l|l|l|}
\hline Construct Variabel & & Laten Variabel & Loading Factor \\
\hline Y1 & $<---$ & Productivity_Y & 0,788 \\
\hline Y5 & $<---$ & Productivity_Y & 0,834 \\
\hline Y10 & $<---$ & Productivity_Y & 0,847 \\
\hline Y11 & $<---$ & Productivity_Y & 0,812 \\
\hline Y12 & $<---$ & Productivity_Y & 0,839 \\
\hline Y14 & $<---$ & Productivity_Y & 0,834 \\
\hline Y16 & $<---$ & Productivity_Y & 0,778 \\
\hline Y17 & $<---$ & Productivity_Y & 0,83 \\
\hline Y21 & $<---$ & Productivity_Y & 0,832 \\
\hline Y23 & $<---$ & Productivity_Y & 0,793 \\
\hline
\end{tabular}

Based on the output of the Research Model above all observed variables / constructs have significant loading factor values in measuring or forming latent variables because the loading factor value $\geq 0.5$ and the path coefficient value of the direct influence of exogenous variables on endogenous variables are statistically significant because CR value> 1, 96. Before the SEM model is used to answer hypotheses, the Full Model must meet several assumptions of discrimant validity.

Discrimant validity aims to measure to what extent a construct is completely different from another construct. The high discriminant value provides evidence that a construct is unique and able to capture the phenomenon being measured. To test discriminatory validity can be done by comparing the correlation between latent variables with the square root Average Variance Extracted ( $\sqrt{ }$ AVE). The measurement model has good discriminant validity if the Average Variance Extracted ( $\sqrt{A V E}$ ) square root value is greater than the correlation between latent variables. The calculation results for discriminant validity testing can be seen in table 13 as follows:

Latent Variable AVE $\sqrt{ }$ AVE

Transformational Leadership Style_X1 $0.581=\sqrt{ } 0.581=0.762$

Communication_X2 $0.535=, 50.535=0.732$

Productivity_Y $0,677=\sqrt{ } 0,677=0.823$ 
Table 13: Correlations between latent variables and Square Root Ave

\begin{tabular}{|l|l|l|l|l|}
\hline Laten Variable & AVE & X1 & X2 & Y \\
\hline $\begin{array}{l}\text { Transformational Leadership } \\
\text { Style_X1 }\end{array}$ & 0,581 & $\mathbf{0 , 7 6 2}$ & & \\
\hline Communication_X2 & 0,535 & $0,213 * *$ & $\mathbf{0 , 7 3 2}$ & \\
\hline \hline Productivity_Y & 0,677 & $0,409 * * *$ & $0,484 * * *$ & $\mathbf{0 , 8 2 3}$ \\
\hline
\end{tabular}

Source: Processed from research results

Based on the table the correlation value of the latent variable Transformational Leadership Style (X1) with other latent variables of 0.213 ; 0.409; smaller than the Average Variance Extracted (VAVE) quadratic root value. Transformational Leadership Style (X1) of 0.762; the correlation value of the latent variable of Communication (X2) with other latent variables of $0.213 ; 0.484$, smaller than the value of the square root Average Variance Extracted ( $\mathrm{AVE}$ ) of Communication (X2) of 0.732; and the correlation value of latent productivity $(\mathrm{Y})$ with other latent variables of $0.409 ; 0484$ is smaller than the value of the square root Average Variance Extracted ( $\mathrm{A}$ VEE) Productivity $(\mathrm{Y})$ of 0.823 . This can be interpreted that each latent variable has good discriminant validity, because all correlation values between latent are lower than the Average Variance Extracted ( $\sqrt{ }$ AVE) quadratic value of each latent variable. Thus it can be concluded that all latent variables in this study are quite unique and able to capture the measured phenomenon.

\section{Hypothesis Testing}

Hypothesis testing using the Structural Equation Modeling (SEM) technique aims to determine whether there is a direct or indirect effect. The direct effect (direct effect) is the influence of the independent variable (exogenous) on the dependent variable (endogenous) while the indirect effect (indirect effect) is the influence of the independent variable (exogenous) on the dependent variable (exogenous)) through other variables or moderating variables. . Testing the direct effect on the research model is done by looking at the value of the path coefficient on each path of the research hypothesis and proceed with the t test (C.R: Critical Ratio) to determine the value of the path coefficient or the value of the influence in the significant category.

a. The second hypothesis is that there is a direct positive influence on the Transformational Leadership Style (X1) on Productivity (Y).

The statistical hypothesis tested is the direct positive effect of the transformational leadership style (X1) on productivity (Y)

Statistical Hypothesis:

$\mathrm{H} 0: \beta \mathrm{y} 2 \square 0$

$\mathrm{H} 1: \beta \mathrm{y} 2>0$

$\mathrm{H} 0$ is rejected, if $\mathrm{CR}(\mathrm{t}$ count $) \geq 1.96$

From the calculation of Structural Equation Modeling the direct effect of the Transformational Leadership Style (X1) on Productivity (Y), the path coefficient value of py2 is 0.201 and CR ( $\mathrm{t}$ count) is 3.715 , because the value of $\mathrm{CR}(3,715) \geq 1.96$, then reject $\mathrm{H} 0$, accept $\mathrm{H} 1$ and can be interpreted that there is a direct effect on the Positive Transformational Leadership Style (X1) on Productivity (Y). The results of the hypothesis analysis provide the finding that the Transformational Leadership Style (X1) has a direct positive effect on Productivity (Y). Transformational leadership will lead to an increase in the productivity of lecturers in private universities to produce and increase productivity of international scientific work. And vice versa, is interpreted to be getting worse Transformational Leadership Style will 
cause a decrease in the Productivity of lecturers in Private Universities to produce and increase productivity of international scientific work which is a measure of productivity or work performance (Kim \& Ployhart, 2014; Upev et.al., 2015)..

This study also strengthens the findings of research (Iqbal et al., 2015) which states that organizational success depends on transfrmational leadership styles, namely leaders who are innovative, productive and supportive (Bushra et al., 2011), sharing Orabi's knowledge (2016: 9), bring change, innovation, foster and increase work motivation in the organizational environment to achieve both personal work targets and team targets (Luthra \& Dahiya, 2015; Veliu et al., 2017), and the transfrmational leadership style has four dimensions consisting of: (1) ideal, charismatic influence, giving vision and mission to gain respect and trust; (2) motivational inspiration, communicating the intended expectations and expressing the importance of goals in a simple way; (3) intellectual simulations, encouraging intelligence and rationality and being careful in solving problems; and (4) individual consideration (Voon et al., 2011); (Veliu et al., 2017); (Ahmad et al., 2014); and (Aydin et al., 2013). Based on the results of research on this hypothesis 1 (one), and supported by the results of previous studies it can be said that the Transformational Leadership Style will be more effectively used in relation to the productivity of lecturers at Private Universities to produce and increase the productivity of international scientific work as an element that influences , i.e. the path coefficient value of pyl is 0.201 and $\mathrm{CR}\left(\mathrm{t}_{\text {count }}\right)$ is 3.715 .

b. Third Hypothesis there is a positive direct effect of Communication (X2) on Productivity (Y)

The statistical hypothesis tested is the positive direct effect of Communication (X3) on Productivity (Y)

Statistical Hypothesis:

H0: $\beta \mathrm{y} 3 \square 0$

$\mathrm{H} 1: \beta \mathrm{y} 3>0$

$\mathrm{H} 0$ is rejected, if $\mathrm{CR}\left(\mathrm{t}_{\text {count }}\right) \geq 1.96$

From the calculation of Structural Equation Modeling the direct influence of Communication (X2) on Productivity (Y) the value of the py3 path coefficient is 0.302 and CR (tcount) is 5.132, because the value of $\mathrm{CR}(5.132) \geq 1.96$, then reject $\mathrm{H} 0$, accept $\mathrm{H} 1$ and $\mathrm{H} 1$ it can be interpreted that there is a positive direct effect of Communication (X2) on Productivity (Y).The results of hypothesis analysis provide findings that Communication (X2) has a direct positive effect on Productivity (Y). This can be interpreted as higher Communication (X2) will cause increased Productivity and vice versa lower communication (X2) will cause a decrease in Productivity of lecturers in Private Universities to produce and increase the productivity of international scientific work. Likewise, on the contrary, is interpreted to be getting worse Communication will cause a decrease in the Productivity of lecturers in Private Universities to produce and increase productivity of international scientific work which is a measure of productivity or performance / work results (Kim \& Ployhart, 2014; Upev et.al., 2015)..

This research also strengthens the findings of research (Sadia et.al., 2016: 34) which states that organizations can run successfully, only if effective organizational communication, namely transferring information or messages from one person to another or to a group and communication leadership (Luthra \& Dahiya, 2015) applied in organizations means less complaining and more work is done, and this eliminates confusion and frees up wasted time that should be spent on explanation (Ajala, 2012) so that it can influence the bottom-line through the communication climate (Luthfie et.al., 2017) is good for increasing employee productivity (Muda et al., 2014; Gusfa et al., 2017).Based on the results of research on this hypothesis 3 , and supported by the results of previous studies it can be said that communication will be more effective and very significant used in relation to the productivity of lecturers in private universities to produce and increase the productivity of international scientific work as an influencing element, namely the path coefficient value of py2 is 0.302 and $\mathrm{CR}\left(\mathrm{t}_{\text {count }}\right)$ is 5.132 ..

\section{Conclusions \& Recomendations}

The results of the analysis of the hypotheses from the study provide findings it can be concluded that:

1. Transformational leadership style (X1) has a direct positive influence on productivity (Y), this can be interpreted as getting better Transformational leadership style will cause increased productivity of 
lecturers in private universities to produce and increase productivity of international scientific work. Likewise, on the contrary, is interpreted to be getting worse Transformational Leadership Style will cause a decrease in the Productivity of lecturers in Private Universities to produce and increase productivity of international scientific work which is a measure of productivity or performance / work results (Kim \& Ployhart, 2014; Upev et.al., 2015 ). This study also strengthens the findings of research (Iqbal et al., 2015) which states that organizational success depends on transfrmational leadership styles, namely leaders who are innovative, productive and supportive (Bushra et al., 2011), sharing Orabi's knowledge (2016: 9), bringing change, innovation, fostering and increasing work motivation in the organizational environment to achieve both personal work targets and team targets (Luthra \& Dahiya, 2015; Veliu et al., 2017)

2. Communication (X2) has a direct positive influence on Productivity (Y), this can be interpreted as higher. Communication (X2) will cause an increase in Productivity and vice versa lower Communication (X2) will cause a decrease in Productivity of lecturers in Private Universities to produce and increase productivity of international scientific work. Likewise, on the contrary, is interpreted to be getting worse Communication will cause a decrease in the Productivity of lecturers in Private Universities to produce and increase productivity of international scientific work which is a measure of productivity or performance / work output (Kim \& Ployhart, 2014; Upev et.al., 2015). This research also strengthens the findings of research (Sadia et.al., 2016: 34) which states that organizations can run successfully, only if effective organizational communication, namely transferring information or messages from one person to another or to a group and communication leadership (Luthra \& Dahiya, 2015) applied in organizations means less complaining and more work is done, and this eliminates confusion and frees up wasted time that should be spent on explanation (Ajala, 2012) so that it can influence the bottom-line through the communication climate (Luthfie et.al., 2017) is good for increasing employee productivity (Muda et al., 2014; Gusfa et al., 2017).

3. The findings of this study are expected to contribute to the Top Management of Private Universities as a reference to be able to encourage and increase the productivity of lecturers producing international scientific work. Then, the findings of this study are expected to be followed up by subsequent researchers by using several other factors that can affect the productivity of lecturers producing international scientific article.

\section{Acknowledgements}

The author would like to thank all academic staff at Trisakti University, Bina Nusantara University, and Tarumanagara University. In this case, the private university is a University that is included in the 50 Great Strengths of Indonesian Scientific Institutions: Scopus Indexed Scientific Publication Profile, showing an overview of scientific publications based on: 1) Number and Growth of Publications; 2) The productivity of the writer; 3) Field of science; 4) Research Collaboration and Place (https://lldikti12.ristekdikti.go.id/2016/12/19/books- strength -50-institutional- scientific-indonesia.html. Accessed April 12, 2018). who participated in this research and it was their contribution that this research was carried out well. I also want to thank the various authors whose work is a source of reference and inspiration for conducting this research.

\section{Reference}

[1.] Aderibigbe, I. A. I. (2017). Relationship between Employee Motivation and Productivity among Bankers in Nigeria. Journal of Economics, 8(1), 76-80. doi:10.1080/09765239.2017.1316964 https://sci-hub.tw/http://dx.doi.org/10.1080/09765239.2017.1316964. Diakses 27 November 2019

[2.] Adu, E. O. (2015). Institutional , Personal and Reward System Factors as Determinants of Teachers ' Productivity in Public Secondary Schools in Oyo State, Nigeria Institutional, Personal and Reward System Factors as Schools in Oyo State , Nigeria, 8923. https://doi.org/10.1080/09718923.2015.11893480

[3.] Agustini, F., Amanah, D., \& Harmen, H. (2014). Lecturer Through Development Of Learning Material In Medan City THE LECTURER EMPOWERMENT FOR INCREASING WORK PRODUCTIVITY OF MANAGEMENT LECTURER THROUGH DEVELOPMENT OF LEARNING MATERIAL, (December 2017). https://doi.org/10.17605/OSF.IO/BXE4P

[4.] Ahmad, F., Abbas, T., Latif, S., \& Rasheed, A. (2014). Impact of Transformational Leadership on 
Employee Motivation in Telecommunication Sector, 2(2), 11-25.

[5.] Ahsanul, I. M. (2013). The Role of Communication Climate in Organizational Effectiveness, 4(7), 155-156.

[6.] Aithal, S. (2016). Munich Personal RePEc Archive How to Increase Research Productivity in Higher Educational Institutions - SIMS Model How to Increase Research Productivity in Higher Educational Institutions - SIMS Model, (71750).

[7.] Ajala, E. M. (2012). THE INFLUENCE OF WORKPLACE ENVIRONMENT ON WORKERS' WELFARE, PERFORMANCE AND PRODUCTIVITY. The African Symposium: An Online Journal of the African Educational Research Network, 12(1), 141-149.

[8.] Al Doghan, M., \& Albar, S. (2015). A Study on Influence of Motivation Factors on Employees Performance in Private Schools in Saudi Arabia, (December), 179-187.

[9.] Aydin, A., Uysal, Ş., \& Sarier, Yi. (2013). The Effect of School Principals ' Leadership Styles on Teachers' Organizational Commitment and Job, 13(2), 806-811.

[10.] BUKU KEKUATAN 50 INSTITUSI ILMIAH INDONESIA Posted by Fitri | Dec 19, 2016 | Litabmas (DP2M), Pengumuman, https://ldikti12.ristekdikti.go.id/2016/12/19/buku-kekuatan-50institusi-ilmiah-indonesia.html.

[11.] Bushra, Fatima; Usman, Ahmad; \& Naveed, Asvir (2011) Effect of Transformational Leadership on Employees' Job Satisfaction and Organizational Commitment in Banking Sector of Lahore (Pakistan) nternational Journal of Business and Social Science Vol. 2 No. 18; 261 file:///C:/Users/user/Downloads/Effect_of_Transformational_Leadership_on_Employees.pdf.

[12.] Caliendo, L., \& Rossi-hansberg, E. (2012). THE IMPACT OF TRADE ON ORGANIZATION, 1393-1467. https://doi.org/10.1093/qje/qjs016.Advance

[13.] Creswell, John W. (2014). Research Design : Qualitative, Quantitative, and Mixed Methods Approaches - 4th ed. p. cm. ISBN 978-1-4522-2609-5 (cloth) — ISBN 978-1-4522-2610-1 (pbk.) Copyright (C) 2014 by SAGE Publications, Inc.

[14.] Direktorat Pengelolaan Kekayaan Intelektual Direktorat Jenderal Penguatan Riset dan Pengembangan Kementerian Riset, Teknologi, dan Pendidikan Tinggi, Copyright (c). (2016).

[15.] Femi, A. F. (2014). The Impact of Communication on Workers ' Performance in Selected Organisations in Lagos State, Nigeria. IOSR Journal Of Humanities And Social Science, 19(8), $75-82$.

[16.] GO, I., \& JE, O. (2015). Arabian Journal of Business and Impact of Leadership Style on Organization Performance: A Critical Literature Review, 5(5). https://doi.org/10.4172/22235833.1000142

[17.] Gusfa, H., Desiyanti, A., \& Ali, H. (2017). Saudi Journal of Humanities and Social Sciences ( SJHSS ) The Effect of Communication Systems , Communication Climate, and Organizational Culture towards Employee Performance in Bureau of General Resources of Koperasi Telekomunikasi Selular Jakarta, 6256, 1297-1308. https://doi.org/10.21276/sjhss.2017.2.12.16.

[18.] Herzberg F, Mausner B, Snyderman B (1959) The motivation to work. New York:John Wiley \& Sons.

[19.] Ifijeh, B. A., Ogbomo, M. O., \& Ifijeh, G. (2018). UTILIZATION OF ACADEMIC LIBRARY RESOURCES FOR RESEARCH PRODUCTIVITY AMONG LECTURERS IN PRIVATE UNIVERSITIES IN SOUTH-SOUTH,

[20.] Iqbal, M. Z., \& Mahmood, A. (2011). Factors Related to Low Research Productivity at Higher Education Level. Asian Social Science, 7(2). doi:10.5539/ass.v7n2p188 https://scihub.tw/10.5539/ass.v7n2p188.

[21.] Iqbal, N., Sha, K., \& Haider, N. (2015). Arabian Journal of Business and Impact of Rewards and Leadership on the Employee Engagement in Con- ventional Banking Sector of Southern Punjab, 5(4), 4-6. https://doi.org/10.4172/2223-5833.1000132

[22.] Kekuatan 50 Besar Insitusi Ilmiah Indonesia : Profil Publikasi Ilmiah Terindeks Scopus oleh Kemenristek Dikti (2016) ISBN 978-602-73921-1-3 Copyright (c) 2016 Direktorat Pengelolaan Kekayaan Intelektual Direktorat Jenderal Penguatan Riset dan Pengembangan Kementerian Riset, Teknologi, dan Pendidikan Tinggi Gedung BPPT II Lt.20, Jl. M.H Thamrin No. 8, Jakarta 10340 http://risbang.ristekdikti.go.id/wp-content/uploads/2018/01/Kekuatan-50-Institusi-Ilmiah- 
Indonesia.pdf.

[23.] Kim, Y., \& Ployhart, R. E. (2014). The Effects of Staffing and Training on Firm Productivity and Profit Growth Before, During, and After the Great Recession, 99(3), 361-389. https://doi.org/10.1037/a0035408

[24.] Kumar R. (2011.) . Research methodology: a step - by - step guide for beginner (3rd ed.). London: SAGE Publication Ltd.

[25.] Kusumandari, Gertruda Tining; Eddy, P.; Silitonga, Sanusi (2018) The Effect of Communication and the Ability of Employee Performance through Motivation in PT CGGS Indonesia International Journal of Business and Applied Social Science (IJBASS) VOL: 4, ISSUE: 6 June 2018 http://ijbassnet.com/ E-ISSN:

2469-6501 https://www.ssoar.info/ssoar/bitstream/handle/document/57863/ssoar-ijbass-2018-6tining_kusumandari_et_al

[26.] Leblebici, D. (2012). IMPACT OF WORKPLACE QUALITY ON EMPLOYEE' S PRODUCTIV ITY : CASE STUDY OF A BANK IN TURKEY, 1(1), 7943.

[27.] Luthfie, M., Hubeis, A. V. S., Saleh, A., \& Ginting, B. (2017). Climate Communication Society Organizations in the Development in the Village Plompong, 4(1), 10-23. https://doi.org/10.5296/jsss.v4i1.9894

[28.] Luthra, A., \& Dahiya, R. (2015). Effective Leadership is all About Communicating Effectively: Connecting Leadership and Communication. InternatIonal Journal of ManageMent \& BusIness StudIes, 5(3), 3-8.

[29.] Muda, I., Rafiki, A., \& Harahap, M. R. (2014). Factors Influencing Employees ' Performance : A Study on the Islamic Banks in Islamic Science University of Malaysia University of North Sumatera, 5(2), 73-80.

[30.] Mustapa, A. N., \& Mahmood, R. (2016). Knowledge Management and Job Performance in the Public Sector : The Moderating Role of Organizational Commitment, 3(7), $28-36$.

[31.] Nordin, S., Sivapalan, S., Bhattacharyya, E., Hashim, H., Fatimah, W., Ahmad, W., \& Abdullah, A. (2014). Organizational Communication Climate and Conflict Management: Communications Management in an Oil and Gas Company. Procedia - Social and Behavioral Sciences, 109, 10461058. https://doi.org/10.1016/j.sbspro.2013.12.587

[32.] Okonedo, S. I. (2015). RESEARCH AND PUBLICATION PRODUCTIVITY OF LIBRARIANS IN PUBLIC DigitalCommons @ University of Nebraska - Lincoln PRODUCTIVITY OF LIBRARIANS IN PUBLIC UNIVERSITIES IN SOUTH-WEST

[33.] PENDIDIKAN TINGGI : 2.250 Profesor tak lakukan riset dan publikasi. https://beritagar.id/artikel/berita/2250-profesor-tak-lakukan-riset-dan-publikasi .

[34.] Peraturan Menteri Pemberdayaan Aparatur Negara dan Reformasi Birokrasi (Permen PAN-RB) Nomor 17 Tahun 2013 tentang Jabatan Fungsional Dosen dan Angka Kreditnya. (n.d.).

[35.] Peraturan Menteri Riset, Teknologi, Dan Pendidikan Tinggi Republik Indonesia Nomor 20 Tahun 2017 Tentang Pemberian Tunjangan Profesi Dosen Dan Tunjangan Kehormatan Professor (Permenristekdikti Nomor 20 Tahun 2017). (n.d.).

[36.] Ruck, K., \& Welch, M. (2012). Public Relations Review Valuing internal communication; management and employee perspectives. Public Relations Review, 38(2), 294-302. https://doi.org/10.1016/j.pubrev.2011.12.016

[37.] Sadia,Aysha; Salleh, Berhannudin Mohd; Abdul Kadir, ,Zulida; \& Sanif, Sazuliana (2016). The Relationship between Organizational Communication and Employees Productivity with New Dimensions of Effective Communication Flow. Journal of Business and Social Review in Emerging Economies ISSN (Online) 2519-0326 (Print) 2519-089X Volume 2: Issue 2 December, Publication at: https://www.researchgate.net/publication/319581045file:///C:/Users/user/Downloads/ayeshasadia.pdf.

[38.] Sageer, A., Rafat, S., \& Agarwal, M. P. (2012). Identification of Variables Affecting Employee Satisfaction and Their Impact on the Organization, 5(1), 32-39.

[39.] Sugiyono (2010). Metode Penelitian Bisnis, Bandung: Alfabeta, cetakan ke-15. 
[40.] Undang - Undang (UU) No 12 Tahun 2012 Tentang Pendidikan Tinggi. (n.d.).; Undang - Undang (UU) No 14 Tahun 2005 Tentang Guru Dan Dosen. (n.d.), and UU No 14 Tahun 2005 pasal 49 ayat 3. (n.d.).

[41.] Upev, M. T., Chorun, M. T., \& Idachaba, J. A. (2015). The Effects of Motivation on Staff Productivity / Performance at the Francis Sulemanuu Idachaba Library , University Of Agriculture, Makurdi-Nigeria, 5(2), 1-7. https://doi.org/10.9790/7388-05230107

[42.] Veliu, L., Manxhari, M., Demiri, V., \& Jahaj, L. (2017). Social sciences THE INFLUENCE OF LEADERSHIP STYLE S ON EMPLOYEE' S PERFORMANCE, 31(2), 59-69.

[43.] Voon, M. ., Ngui, K. S., Lo, M. ., \& Ayub, N. . (2011). The influence of leadership styles on employees' job satisfaction in public sector organizations in Malaysia, 2(1), 24-32. 